\title{
The Effect of Education to Indonesian Economic Growth
}

\author{
Rifa'atul Mahmudah
}

\section{ARTICLE INFO \\ Article History: \\ Received 05.09.2018 \\ Received in revised form \\ 26.12.2018 \\ Accepted \\ Available online 01.04.2019}

\begin{abstract}
Economic growth is a target that the economy seeks to achieve in the long run, and as closely as possible consistent with economic growth in the short term. Economic growth can explain and simultaneously measure the achievement of an ec onomic development, both within the country. The analy sis to ol used is a simple linear regression. The result of the analy sis shows that education value has a positive effect on economic growth in Indonesia period $2000-2015$. The contribution given by education to economic growth is $40,9 \%$ and the rest is influenced by other variables such as consumption, investment, and government expenditure variable.
\end{abstract}

(C) IJERE. All rights reserved

Keywords:

Education, economic growth, education

\section{INTRODUCTION}

Economic growth is a target that the economy seeks to achieve in the long run, and as closely as possible consistent with economic growth in the short term. Economic growth can explain and simultaneously measure the achievement of an economic development, both within the country. Mankiw (2003) states that economic growth is one of the important indicators to see the success of economic development in a country in addition to other indicators such as unemployment rate, poverty rate, inflation rate, and so on.

High economic growth in the era of regional autonomy is also one of the economic goals of a region. Many factors influence the economic grow th of a region, one of the factors that influence economic grow th is human resources (education). The education sector is considered to play a leading role in shaping the ability of a developing country to absorb modern technology and develop production capacity to create grow th as well sustainable development (Todaro, 2006).

Sukirno (2004) education is an investment that is very useful for economic development. Thus education can be included as a development investment whose results can be enjoyed later on. This shows that Education has an important role in the life of the nation and state in an effort to create quality human resources so that it has a direct impact on the economic grow th of a region through increased skills and work productivity. Thus education is expected to overcome economic backwardness through increasing human capabilities so as to improve people's welfare.

Based on the phenomenon, the researchers are interested to conduct research with the title: The Effect of Education Value on Economic Growth in Indonesia Period Year 2000 - 2015.

Literature Review and Hypotheses

\section{Education}

Education, like the nature of its target, which is human, contains many aspects and properties are very complex. As a process of cultural transformation,education is defined as the activity of cultural inheritance from generation to generationother genarians. As a process of personal formation, peducation is interpreted as a to sistematic activitytis and systemic directed towards the formation personality of students (Tirtarahardja et al., 2005).

Education will have a positive effect on the economic activity of the country, as it represents the expenditure of the population of other countries on the goods produced domestically. Implementation of education payments is made by cash or credit, which can be done by: advance payment, Letter of Credit (L/ C), draft note with condition against document against payment and document against acceptance, (open account), consignment, and other payments that are customary in foreign trade in accordance with the agreement between the seller and the buyer (Sukirno, 2013). 
Mahmudah,R. (2019). The effect of education to Indonesian economic growth. International Journal of Educational Research Review, 4(2),140-145.

The important function of the education component of foreign trade is that the State gains and national income rises, which in turn increases the amount of output and economic growth. With higher output levels the vicious cycle of poverty can be broken and economic development can be improved (Jhingan, 2010).

\section{Economic Growth}

According to Kuznet, economic grow th is the long-term capacity-building of the country concerned to provide various economic goods to its population. The increase in capacity itself is determined or made possible by the progress or settlements of various demands of existing circumstances (Todaro, 2000).

Economic grow th means the fiscal proliferation of goods and services and the increase in capital goods production. An economy is said to experience economic growth if the number of goods and services is increasing. In the real world, it is very difficult to record the number of units of goods and services produced during a given period. Because the number used to estimate the output is the monetary value (money) that is reflected in the value of Gross Domestic Product (GDP) (Sukirno, 2013). To measure economic grow th, the value of GDP used is GDP based on constant prices. Because, using constant prices, the effect of price changes has been eliminated, so even if the figures appear are the money value of the output of goods and services, the change in GDP value simultaneously shows the change in the number of goods and services produced during the observation period. (Manurung and Rahardja, 2008). The classical model can be developed further, so that we can write the equation, $Q=f(K, L, T, U, M, W, I)$

Where:

$\mathrm{Q}=$ output or GDP; $\mathrm{K}=$ capital goods; $\mathrm{L}=$ labor; $\mathrm{T}=$ technology; $\mathrm{U}=$ money; $\mathrm{M}=$ management; $\mathrm{W}=$ entrepreneurship; $\mathrm{I}=$ information

The above equation simply shows the factors that determine economic growth. Here are the determinants of economic growth: Capital Goods, Labor, Technology, Money, Management, Entrepreneurship, and Information.

The theory of economic growth can be defined as an explanation of what factors determine longterm increases in output per capita, and an explanation of how these factors interact with each other, resulting in a growth process. So the theory of growth is nothing but a logical account of how the growth process occurs (Boediono, 2009).

Furthermore, according to Manurung and Rahardja (2008) theories of economic growth see the relationship between economic growth with determinants of economic growth. The differ ence between one theory and another lies in the different focus of discussion and or assumptions used.

\section{a. Schumpeter Theory}

According to Sukirno (2013), Schumpeter's theory emphasizes the importance of entrepreneurs' funding in realizing economic growth. In theory, it is shown that entrepreneurs are a group that will continuously make renewal or innovation in economic activity. These innovations include: introducing new goods, enhancing the efficient way of producing things, expanding the market of goods in to new markets, developing new sources of raw materials and making changes in the organization with the aim of enhancing the efficiency of corporate activities.In his theory of growth Schumpeter begins his analysis by asserting that the economy is in a state of undeveloped. According to Schumpeter the higher the rate of progress of an economy the more limited the possibility of innovation. Then the economic growth will become slowly progressing (Sukirno, 2013).

\section{b. Neo-Classical Grow th Theory}

According to Sukirno (2013), this theory was developed by Abraham Movies and Solow who stated that economic growth depends on the development of factors of production. In the equation, this view can be expressed by the equation: $\mathrm{Y}=\mathrm{f}(\mathrm{K}, \mathrm{L}, \mathrm{T})$

Where: $\mathrm{Y}$ is the rate of economic growth, $\mathrm{K}$ is the growth rate of capital, $\mathrm{L}$ is the rate of population grow th is the rate of technological development. Solow analysis further forms the mathematical formula for 
the equation and so makes empirical studies of evidence to show the following conclusion: the most important factor that embodies economic growth is not capital increase and labor increase. The most important factors are technological progress and the increase of skill and workmanship (Sukirno, 2013).

According to Manurung and Rahardja (2008), the focus of discussion of neo-classical grow th theory is the accumulation of the stock of capital goods and related to the decision of society to save or make the investment. The important assumptions of the Solow model include: The technological level is considered constant (no technological advancement), The depreciation rate is considered constant, No foreign trade or capital inflow, No government sector, The rate of population grow th (labor) are also considered constant. To facilitate the analysis, it can be assumed that the entire population is working, so the population = the amount of labor.

Based on the above literature review, we propose the hypothesis in this study is suspected to have a significant influence on the value of education to economic growth in Indonesia Period Year 2000 - 2015.

Previous research is done Sumiyarti (2015) using OLS approach, more focus on the influence of education manufacturing to economic growth in Indonesia. It $w$ as found that the education of the manufacturing sector had a positive and significant impact on economic growth. In line with Sumiyarti (2015), Solomon \& Hubarat (2007) found that in the long term education have a significant effect on economic growth.

Research by Mohsen (2015) examines the impact of education and imports on Syrian economic growth. Using the Johansen Cointegration test shows that education and imports have a positive and significant influence on the gross domestic product (GDP). The analysis of variance decomposition shows that on the Estimated 10 -year horizon, education and import shocks account for $28 \%$ and $25 \%$ of the predicted GDP false variance.

\section{Research Methods}

The scope of this study is to discuss the problems related to the effect of education on economic grow th in Indonesia

The data used is the annual data from the Central Bureau of Statistics. The data used are secondary data in the form of time series data from 2000 to 2015 in Indonesia. Data were obtained from several sources, including Central Bureau of Statistics, Bank Indonesia.

The method of analysis used in this research is descriptive qualitative and quantitative analysis. The Qualitative descriptive analysis is used to describe phenomena related to the problems studied, while quantitative analysis is used to analyze quantitative information that is data that can be measured, tested, and informed in the form of equations, tables, and so forth. The quantitative analysis step consists the estimation of regression model by using time series data, simple linear equation regression using OLS (Ordinary Least Squares) method and statistical test.

\section{Simple Regression Model}

$$
\mathrm{Y}=\beta 0+\beta 1 \text { Education+ et }
$$

Where: $\beta 0$ : constants; $\beta 1$ : regression coefficient; and Education: Education Value

\section{Hypothesis testing}

This test is performed to find out how much influence of variable independently partially (individual) to the dependent variable using $\mathrm{t}$-test $w$ ith the following criteria:

a. Formulating Hypotheses

Ho: $b i=0$, that is, there is no effect of the ke-i variable to the dependent variable.

Ha: $b i \neq 0$, meaning there is the influence of ke-i variable to dependent variable

b. Determining the decision area

If the value of $\mathrm{t}$-arithmetic $>\mathrm{t}$-table, then Ho is rejected and Ha accepted, it means there is an independent variable influence on the dependent variable 
Mahmudah,R. (2019). The effect of education to Indonesian economic growth. International Journal of Educational Research Review, 4(2),140-145.

If the value of $t$-count $<\mathrm{t}$-table, then Ha rejected and Ho accepted, meaning there is no influence of independent variables on the dependent variable

\section{Determination Coefficient Analysis}

To find out how many Education Value influence to Economic Growth In Indonesia period 2000 2015, analysis of coefficient of determination (R). The value of $R$ can be calculated by the following equation (Santoso, 2004): $\mathrm{R}=\mathrm{r} 2 \times 100 \%$.

Description: $\mathrm{R}=$ Coefficient of Determination; and $\mathrm{r}=$ Correlation Coefficient

\section{Analysis and Discussion}

Analysis Results

Based on the results of simple linear regression analysis in table 1. using SPSS application obtained the following results.

$$
\mathrm{Y}=-0.733+0.206 \text { Education }
$$

This shows that the constant value of -0.733 means that if there is no Education then the level of Economic Growth at the constant value is -0.733 . The value of 0.206 indicates that if there is an increase in education of 0.206 million US \$ then Economic Growth also increased by 0.206 percent with the assumption ceteris paribus.

Table 1. Results of Coefficients

\begin{tabular}{|c|c|c|c|c|c|}
\hline \multirow[t]{2}{*}{ Model } & \multicolumn{2}{|c|}{ Unstandardized Coefficients } & \multirow{2}{*}{$\begin{array}{c}\text { Standardized } \\
\text { Coefficients }\end{array}$} & \multirow[t]{2}{*}{$\mathrm{t}$} & \multirow[t]{2}{*}{ Sig. } \\
\hline & B & Std. Error & & & \\
\hline $\begin{array}{l}\text { Constant } \\
\text { Ekspor }\end{array}$ & $\begin{array}{r}-0,733 \\
0,206 \\
\end{array}$ & $\begin{array}{r}0,768 \\
0,066 \\
\end{array}$ & 0,640 & 3,114 & 0 \\
\hline
\end{tabular}

The $t$-count value of 3.114 is greater than the $t$-table value of 2.131 which means Ho is rejected and Ha accepted, meaning there is the influence of Education Value on Economic Growth in Indonesia Period Year $2000-2015$. The result of $t$-count is greater than $\mathrm{t}$-table at $95 \%$ confidence level and $5 \%$ significance level can be described as follows:

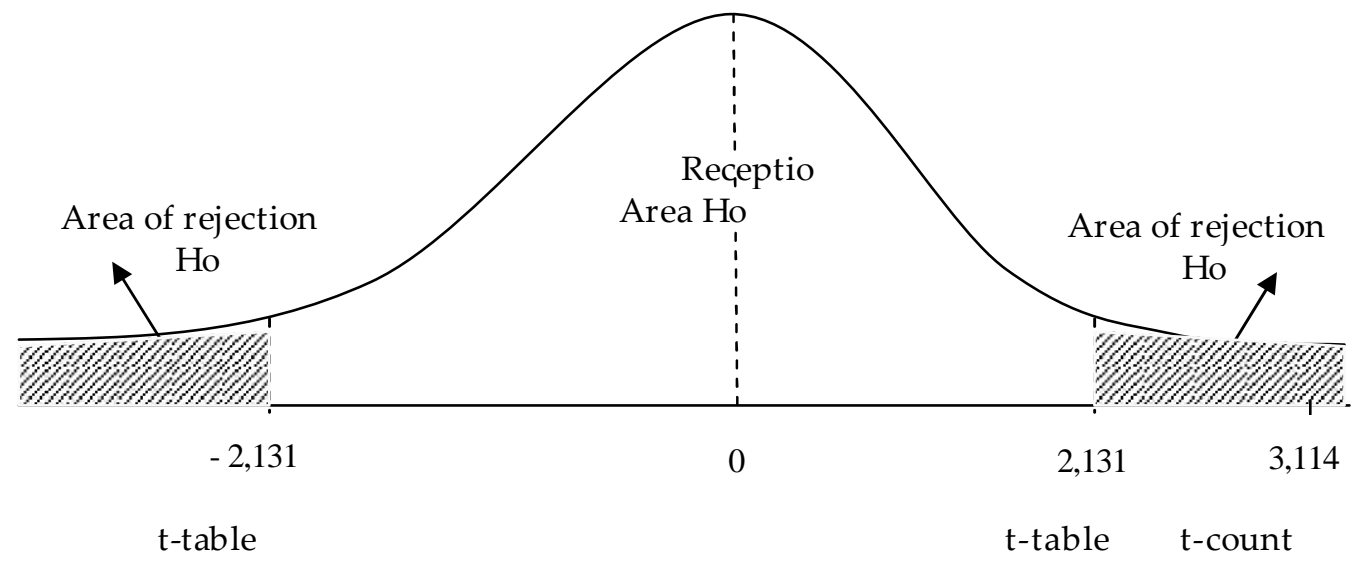

Figure 2. Test t Level 95\% Confidence To Test Two Sides

Tabel 2. Model Summary

$\begin{array}{llll}\text { Model } & \text { R } & \text { R Square } & \text { Adjusted R }\end{array}$


Mahmudah,R. (2019). The effect of education to Indonesian economic growth. International Journal of Educational Research Review, 4(2),140-145.

\begin{tabular}{cccc}
\hline & & & Square \\
\hline 1 & 0,640 & 0,409 & 0,367 \\
\hline
\end{tabular}

Based on Table 2, the value of $\mathrm{R}$ Square is 0,409 , meaning that the contribution given by Education Value to Economic Grow th is $40,9 \%$ and the rest $59,1 \%$ is influenced by other variables that do not exist in this research such as consumption, investment, and government expenditure.

\section{Discussion}

Based on the results of the analysis can be explained that the value of education positively affects the economic growth in Indonesia. This is in accordance with the classical theory proposed by Schumpeter Theory emphasizes the importance of entrepreneurs' funding in realizing economic growth. In theory, it is shown that entrepreneurs are a group that will continuously make renewal or innovation in economic activity. These innovations include: introducing new goods, enhancing the efficient way of producing things, expanding the market of goods into new markets, developing new sources of raw materials and making changes in the organization with the aim of enhancing the efficiency of corporate activities.

By developing the production of goods and services to the international market in the form of education it can indirectly increase the rate of economic growth. This is what happens in Indonesia when viewed in table 3 can be seen clearly that when the year 2000 up to the year 2011 the value of education increased the rate of economic grow th of Indonesia also increased and vice versa in 2012 until the year 2015 the value of education fell, if the value of education decreased then economic grow th also decreased.

Based on the analysis results stated that in the period 2000 - 2015 education variables have a positive and significant effect on GDP. A positive relationship between education and economic growth over the long term suggests that the policy of promoting education will have long-term impacts. This means that if the government continues to increase education, then in the long term such influence will be a factor that can increase the GDP of Indonesia. The increased value of education can increase APBN revenue and maintain the stability of the trade balance. In accordance with the theory of Keynes states that education greater than imports can increase GDP. Also, the theory of education base that states to achieve high economic growth, then the strategy of educationing is the right step.

\section{Conclusion}

Based on the results of analysis and discussion can be concluded that Education value positively affected the level of economic growth in Indonesia period 2000-2015. the contribution given by education to Economic Growth is $40.9 \%$ and the remaining $59.1 \%$ is influenced by other variables such as consumption, investment, and government expenditure variables. that in order to increase economic grow th it is necessary to improve the performance of Indonesian education. The improvement of Indonesia's education performance can be done in many ways, one of them is by improving the education administration system, increasing the research and development of Indonesian products, improving infrastructure facilities and infrastructure, exchange rate stability and non-traditional market expansion.

\section{REFERENCES}

BPS. (2015). Statistik Indonesia. Jakarta: BPS.

Boediono. (2009). Theory of economic growth, Yogyakarta: BPFE

Jhingan, ML. (2010). Ekonomi pembangunan dan perencanaan. Jakarta: PT Rajagrafindo Persada.

Mankiw, N. Gregory. (2003). Theory of economic growth (translate), PT. Gramedia Pustaka Utama, Jakarta.

Muhibbin Syah.2010. Psikologi Pendidikan dengan pendekatan baru. Bandung: PT Remaja Rosdakarya 
Mahmudah,R. (2019). The effect of education to Indonesian economic growth. International Journal of Educational

Research Review, 4(2),140-145.

Mohsen, A.S. (2015). Effects of education and imports on the economic growth of Syria. Euro-Asian Journal of Economics and Finance, 3(4), 253-261.

Rahardja, Prathama dan Mandala Manurung. (2008). Macroeconomic Theory An Introduction. Faculty of Economics, University of Indonesia. Jakarta

Safari, M. F. (2016). Analysis of the Influence of Education, Capital Formation, and Government Expenditure on Economic Growth of Indonesia. Diponegoro University. Semarang

Sedyaningrum, Mirantika dkk. (2016). The Effect of Total Education Value, Import, and Economic Grow th on Exchange Rate and Public Buying Power in Indonesia (Case Study at Bank Indonesia Period of 2006: IV - 2015: III). Journal of Business Administration. Volume 34 No. 1. May 2016..

Santoso, S. (2004). SPSS Parametric Statistics Book Training. Jakarta: PT Elek Media Komputindo

Sukirno, S. (2013). Introduction to Macroeconomic Economics Theory. Jakarta: PT. Raja Grafindo Prasada

Sumiyarti (2015). Is the hypothesis "Education Led Growth" applicable in Indonesia. Journal of Economics and Development Studies. Vol.16(2).pp.188-199.

Salomo, R., dan P.M. Hutabarat (2007). The role of international trade as one of the sources of Indonesia's economic growth. Paper: Presented at the Graduate Seminar of Economic Sciences University of Indonesia on December 13, 2007 at the University of Indonesia Depok.

Todaro MP., \& Smith, S.P. (2006). Economic development. Ninth Edition. Pearson Education Limited dan Erlangga. Jakarta. 